\title{
Modulation of Synaptic Transmission by Nociceptin/Orphanin FQ and Nocistatin in the Spinal Cord Dorsal Horn of Mutant Mice Lacking the Nociceptin/Orphanin FQ Receptor
}

\author{
SEIFOLLAH AHMADI, CAROLIN KOTALLA, HANS GÜHRING, HIROSHI TAKESHIMA, ANDREAS PAHL, and \\ HANNS ULRICH ZEILHOFER \\ Institut für Experimentelle und Klinische Pharmakologie und Toxikologie, Universität Erlangen-Nürnberg, Erlangen, Germany (S.A., C.K., H.G., \\ A.P., H.U.Z.); and Division of Cell Biology, Institute of Life Science, Kurume University, Fukuoka, Japan (H.T.)
}

Received August 9, 2000; accepted December 1, 2000

This paper is available online at http://molpharm.aspetjournals.org

\begin{abstract}
Nociceptin/orphanin FQ (N/OFQ) and nocistatin (NST) are two neuropeptides derived from the same precursor protein that exhibit opposing effects on spinal neurotransmission and nociception. Here, we have used whole-cell, patch-clamp recordings from visually identified neurons in spinal cord dorsal horn slices of genetically modified mice to investigate the role of the $\mathrm{N} / \mathrm{OFQ}$ receptor (N/OFQ-R) in the modulatory action of both peptides on excitatory glutamatergic and inhibitory glycinergic and $\gamma$-aminobutyric acid (GABA)-ergic synaptic transmission. In wild-type mice, N/OFQ selectively suppressed excitatory transmission in a concentration-dependent manner but left inhibitory synaptic transmission unaffected. In contrast, NST reduced only inhibitory but not $\alpha$-amino-3-hydroxy-5-methylisoxazole4-propionic acid (AMPA) receptor-mediated excitatory synaptic
\end{abstract}

transmission. N/OFQ-mediated inhibition of excitatory transmission was completely absent in N/OFQ-R receptor-deficient (N/OFQ- $\mathrm{R}^{-1-}$ ) mice and significantly reduced in heterozygous (N/OFQ- $\mathrm{R}^{+/-}$) mice, whereas the action of NST on inhibitory neurotransmission was completely retained. To test for the relevance of these results for spinal nociception, we investigated the effects of intrathecally injected N/OFQ in the mouse formalin test, an animal model of tonic pain. N/OFQ (3 nmol/ mouse) induced significant antinociception in wild-type mice, but had no antinociceptive effects in N/OFQ- $\mathrm{R}^{-1-}$ mice. These results indicate that the inhibitory action of N/OFQ on excitatory glutamatergic synaptic transmission and its spinal antinociceptive action are mediated via the N/OFQ receptor, whereas the action of NST is independent of this receptor.
Nociceptin/orphanin FQ (N/OFQ; Meunier et al., 1995; Reinscheid et al., 1995) and nocistatin (NST; Okuda-Ashitaka et al., 1998) are two neuropeptides, which have been implicated in several CNS functions including nociception. N/OFQ is an endogenous agonist at the opioid receptor-like 1 receptor (Meunier et al., 1995; Reinscheid et al., 1995), which is also called ROR-C, LC132, or, most recently, NOP, OP-4, or N/OFQ receptor (Bunzow et al., 1994; Fukuda et al., 1994; Mollereau et al., 1994, Nishi et al., 1994; Wang et al., 1994). Both pro- and antinociceptive effects of exogenously applied N/OFQ have repeatedly been reported, mainly depending on the dose and site of application (e.g., Inoue et al., 1999; for a recent review, see Calo'G et al., 2000). Whereas pronociceptive (Meunier et al., 1995; Reinscheid et al., 1995) and/or antiopioidergic effects (Mogil et al., 1996) dominate after intracerebroventricular injection, antinociception is reliably

This work was supported by a grant from the Deutsche Forschungsgemein schaft to H.U.Z. and A.P. (SFB 353/A8). observed after spinal application of nanomolar doses in a variety of mouse and rat pain models (e.g., Xu et al., 1996; Erb et al., 1997; Inoue et al., 1999).

NST is derived from the same precursor protein as N/OFQ, preproN/OFQ (ppN/OFQ; Saito et al., 1995; Houtani et al., 1996; Nothacker et al., 1996; Pan et al., 1996), and has been demonstrated to antagonize several effects of N/OFQ at the cellular and behavioral levels (Minami et al., 1998; Nicol et al., 1998; Okuda-Ashitaka et al., 1998; Zhao et al., 1999). Several lines of evidence suggest that NST is a biologically active peptide per se that is involved in nociception at the spinal level (Xu et al., 1999; Nakano et al., 2000; Zeilhofer et al., 2000).

In the spinal cord dorsal horn, which constitutes the first important site of synaptic integration in the pain pathway (Yaksh and Malmberg, 1994), both the precursor protein of $\mathrm{N} / \mathrm{OFQ}$, ppN/OFQ, and the presumed targets of $\mathrm{N} / \mathrm{OFQ}$, N/OFQ receptors, are expressed (Narita et al., 1999; Houtani 
et al., 2000). L-glutamate and glycine, together with GABA, serve as the major excitatory and inhibitory neurotransmitters in this CNS area, respectively (Doubell et al., 1999). We have previously shown that N/OFQ selectively inhibits excitatory glutamatergic synaptic transmission in the rat spinal cord dorsal horn via a presynaptic naloxone-insensitive mechanism (Liebel et al., 1997). In contrast, NST selectively reduced the release of the inhibitory neurotransmitters glycine and GABA and left $\alpha$-amino-3-hydroxy-5-methylisoxazole-4-propionic acid receptor-mediated synaptic transmission unaffected (Zeilhofer et al., 2000). Although inhibition of excitatory synaptic transmission can be competitively antagonized by the partial N/OFQ receptor antagonist phe ${ }^{1} \psi\left(\mathrm{CH}_{2}-\right.$ $\mathrm{NH}) \mathrm{Gly}^{2}$ ]-nociceptin-(1-13) $\mathrm{NH}_{2}$ (developed by Guerrini et al., 1998), reduction of inhibitory synaptic transmission by NST is insensitive to $\left.\mathrm{phe}^{1} \psi\left(\mathrm{CH}_{2}-\mathrm{NH}\right) \mathrm{Gly}^{2}\right]$-nociceptin-(113) $\mathrm{NH}_{2}$ (Ahmadi et al., 2001). These findings suggest that both peptides act via different receptors and specifically target excitatory and inhibitory transmitter release in the spinal cord dorsal horn.

The generation of mice deficient in N/OFQ receptors (Nishi et al., 1997) opened the possibility to directly investigate the role of the N/OFQ receptor in the mediation of the cellular effects of N/OFQ and NST. Here, we show that the inhibitory effect of N/OFQ on spinal excitatory glutamatergic synaptic transmission is completely absent in mice lacking N/OFQ receptors, whereas the suppression of inhibitory synaptic transmission by NST is completely retained in these mice. In addition, we show that in the mouse formalin test, N/OFQ induces antinociception in wild-type mice after intrathecal injection, but has no effects on the nociceptive behavior in $\mathrm{N} / \mathrm{OFQ}-\mathrm{R}^{-\prime-}$ mice.

\section{Experimental Procedures}

Animals. Experiments were carried out on mutant mice lacking the N/OFQ receptor ( morc $^{\mathrm{m} 1}$; Nishi et al., 1997), in wild-type mice and in mice heterozygous for this gene. All mice used in our experiments were bred from heterozygous pairs of mice $(75 \% \mathrm{C} 57 \mathrm{BL} / 6 \mathrm{~J}$, $25 \% 129$ strain).

Slice Preparation and Electrophysiological Recordings. Mice of either sex that were 10 to 16 days old were killed in ether narcosis by decapitation. Transverse slices of the lumbar spinal cord $(250 \mu \mathrm{m}$ thick) were prepared as described previously (Liebel et al., 1997; Zeilhofer et al., 2000). The tips of the mouse tails were stored at $-70^{\circ} \mathrm{C}$ for post hoc genotyping. Whole-cell, patch-clamp recordings were performed from neurons identified under visual control using the infrared gradient contrast technique coupled to a video microscopy system (Dodt and Zieglgänsberger, 1994). Slices were completely submerged and continuously superfused with external solution, which contained $125 \mathrm{mM} \mathrm{NaCl}, 26 \mathrm{mM} \mathrm{NaHCO}, 1.25 \mathrm{mM}$ $\mathrm{NaH}_{2} \mathrm{PO}_{4}, 2.5 \mathrm{mM} \mathrm{KCl}, 2 \mathrm{mM} \mathrm{CaCl} 2,1 \mathrm{mM} \mathrm{MgCl}$, and $10 \mathrm{mM}$ glucose, $\mathrm{pH} 7.30,315 \mathrm{mOsM}$ ) and was bubbled with $95 \% \mathrm{O}_{2} / 5 \% \mathrm{CO}_{2}$. Patch pipettes (4-5 M $\Omega$ ) were filled with internal solution containing $130 \mathrm{mM}$ K-gluconate, $20 \mathrm{mM} \mathrm{KCl}, 2 \mathrm{mM} \mathrm{MgCl}_{2}, 0.05 \mathrm{mM}$ EGTA, 3 mM Na-ATP, $0.1 \mathrm{mM}$ Na-GTP, and $10 \mathrm{mM}$ Na-HEPES, pH 7.30. QX-314 (5 mM) was added to the internal solution to block voltageactivated sodium currents. Excitatory and inhibitory postsynaptic currents (EPSCs and IPSCs) were evoked at a frequency of 0.1-0.07 $\mathrm{Hz}$ and recorded at a holding potential of $-80 \mathrm{mV}$ at room temperature. Short hyperpolarizing voltage steps to $-90 \mathrm{mV}$ were applied every minute to monitor input and access resistance. EPSCs and IPSCs were elicited by ipsilateral extracellular electrical stimulation (100 $\mu \mathrm{s}, 3-10 \mathrm{~V})$ using a glass electrode filled with $1 \mathrm{M} \mathrm{NaCl}$. Peptide- or drug-containing solutions were bath applied at a rate of
1 to $2 \mathrm{ml} / \mathrm{min}$. Percentage inhibition of postsynaptic currents by $\mathrm{N} / \mathrm{OFQ}$ and NST was determined from the average amplitude of 10 consecutive postsynaptic currents evoked immediately before application of the peptides and when a steady state of inhibition was reached, usually about 3 min after peptide application.

Behavioral Testing. The pro- and/or antinociceptive effects of N/OFQ were analyzed in the formalin test (Dubuisson and Dennis, 1977), which has been adapted to mice. Experiments were performed at room temperature. Male mice, 7 to 9 weeks old, were briefly anesthetized with isoflurane and intrathecally injected at the level of the lower lumbar spine with N/OFQ or vehicle $(0.9 \% \mathrm{ACSF})$ in a total volume of $5 \mu \mathrm{l}$. A small amount of black ink (1\% v/v) was added to the peptide or vehicle containing solutions to allow post hoc verification of proper intrathecal injection. Only mice with normal postinjection behavior and unimpaired motor function were used. Wild-type and $\mathrm{N} / \mathrm{OFQ}-\mathrm{R}^{-1-}$ mice were randomly assigned to the different treatment groups consisting of 10 animals each. Formalin $(10 \mu \mathrm{l}, 5 \%)$ was injected subcutaneously into the dorsal surface of the left hind paw 10 min after intrathecal injection of N/OFQ or vehicle. At this time point, mice had completely recovered from light isoflurane narcosis. Flinches of the injected paw were counted at 1-min intervals for 60 min after formalin injection. After the tests, mice were killed by $\mathrm{CO}_{2}$ inhalation and proper intrathecal injection was verified by visual inspection after laminectomy. All behavioral tests and the killing of the animals were performed in accordance with the institutional guidelines of the University of Erlangen-Nürnberg.

Genotyping. The genotype of the animals was determined with PCR using the following primer pairs: Wild-type N/OFQ-R gene, 5'-GCC CAT CGA GGT GTT CAT GTG CCT GT and 5'-GAC CCG CCT ACC TGA GGA TGA CAT AC; targeted N/OFQ-R gene, $5^{\prime}$-GCC CAT CGA GGT GTT CAT GTG CCT GT, and 5'-CAA TAT CGC GGC TCA GTT CGA GGT GC.

Peptides. NST (bovine) and methionine-enkephalin (met-enk) were purchased from Tocris (Bristol, UK). N/OFQ was obtained from Dr. M. Herkert (Institut für Biochemie, Universität Erlangen-Nürnberg, Germany) and from Tocris. Peptides (purity $>95 \%$ ) were dissolved in external recording solution and stored in aliquots (1 $\mathrm{mM})$ at $-20^{\circ} \mathrm{C}$. Fresh dilutions were made with standard external solution on every experimental day.

Statistical Analysis. All measurements are given as mean \pm S.E.M. Statistical testing for significant inhibition against the null hypothesis "no inhibition" was done with the one-sample sign test. Significant differences in the degree of inhibition were evaluated using ANOVA ( $\alpha=0.05$ ) followed by Fisher's post hoc test.

\section{Results}

Effects of N/OFQ and NST on Excitatory and Inhibitory Synaptic Transmission in the Mouse Spinal Cord Dorsal Horn. The effects of N/OFQ and NST on excitatory synaptic transmission were tested in superficial dorsal horn neurons of the mouse spinal cord using whole-cell, patchclamp recordings. Excitatory synaptic transmission was studied in the presence of the $\mathrm{GABA}_{\mathrm{A}}$ receptor blocker bicuculline $(10 \mu \mathrm{M})$ and the glycine receptor blocker strychnine (2 $\mu \mathrm{M})$. EPSCs evoked by extracellular electrical stimulation of the dorsal root entry zone and recorded at a holding potential of $-80 \mathrm{mV}$ were mediated by ionotropic glutamate receptors as indicated by their sensitivity to a combination of the $N$-methyl-D-aspartate and non- $N$-methyl-D-aspartate receptor antagonists, D-APV $(50 \mu \mathrm{M})$ and CNQX $(10 \mu \mathrm{M})$, respectively. At this holding potential, EPSCs were almost exclusively mediated by $\alpha$-amino-3-hydroxy-5-methylisoxazole-4propionic acid receptors.

In the first series of experiments, N/OFQ and NST were applied consecutively at a saturating concentration $(10 \mu \mathrm{M})$. 
As previously shown in Sprague-Dawley rats (Zeilhofer et al., 2000), N/OFQ and NST turned out to be specific inhibitors of excitatory or inhibitory synaptic transmission, respectively. EPSCs were insensitive to NST $\triangle$ EPSC amplitude: $3.1 \pm$ $3.4 \%$ (mean \pm S.E.M.), $n=10$ ), but were reduced in amplitude by N/OFQ (10 $\mu \mathrm{M})$ by $37.3 \pm 5.4 \%$ ( $n=10$; Fig. $1, \mathrm{~A}$ and C). In contrast, IPSCs, which were recorded in the presence of CNQX (10 $\mu \mathrm{M})$ and APV $(50 \mu \mathrm{M})$, remained almost unchanged when N/OFQ was applied ( $\triangle$ IPSC amplitude, $1.3 \pm$ $4.8 \% ; n=10$ ) but were significantly reduced by $41.6 \pm 3.9 \%$ in the presence of NST (10 $\mu \mathrm{M}$; Fig. 1, B and C).

Lack of Spinal EPSC Inhibition by N/OFQ in N/OFQ$\mathbf{R}^{-/-}$Mice. We next compared the effects of N/OFQ $(10 \mu \mathrm{M})$ on excitatory glutamatergic transmission in wild-type, heterozygous and N/OFQ- $\mathrm{R}^{-1-}$ mice. N/OFQ-mediated inhibition was statistically significant in wild-type mice (40.8 \pm $3.8 \% ; n=19 ; p \leq 0.001)$ and heterozygous mice $(23.2 \pm 4.1 \%$; $n=10 ; p \leq 0.001)$, but not in N/OFQ-R-/- mice $(4.1 \pm 2.1 \%$; $p=0.77$; Fig. 2A) indicating a pronounced gene dose effect of $\mathrm{N} / \mathrm{OFQ}$ receptor expression in the mouse spinal cord dorsal horn (Fig. 2 B).

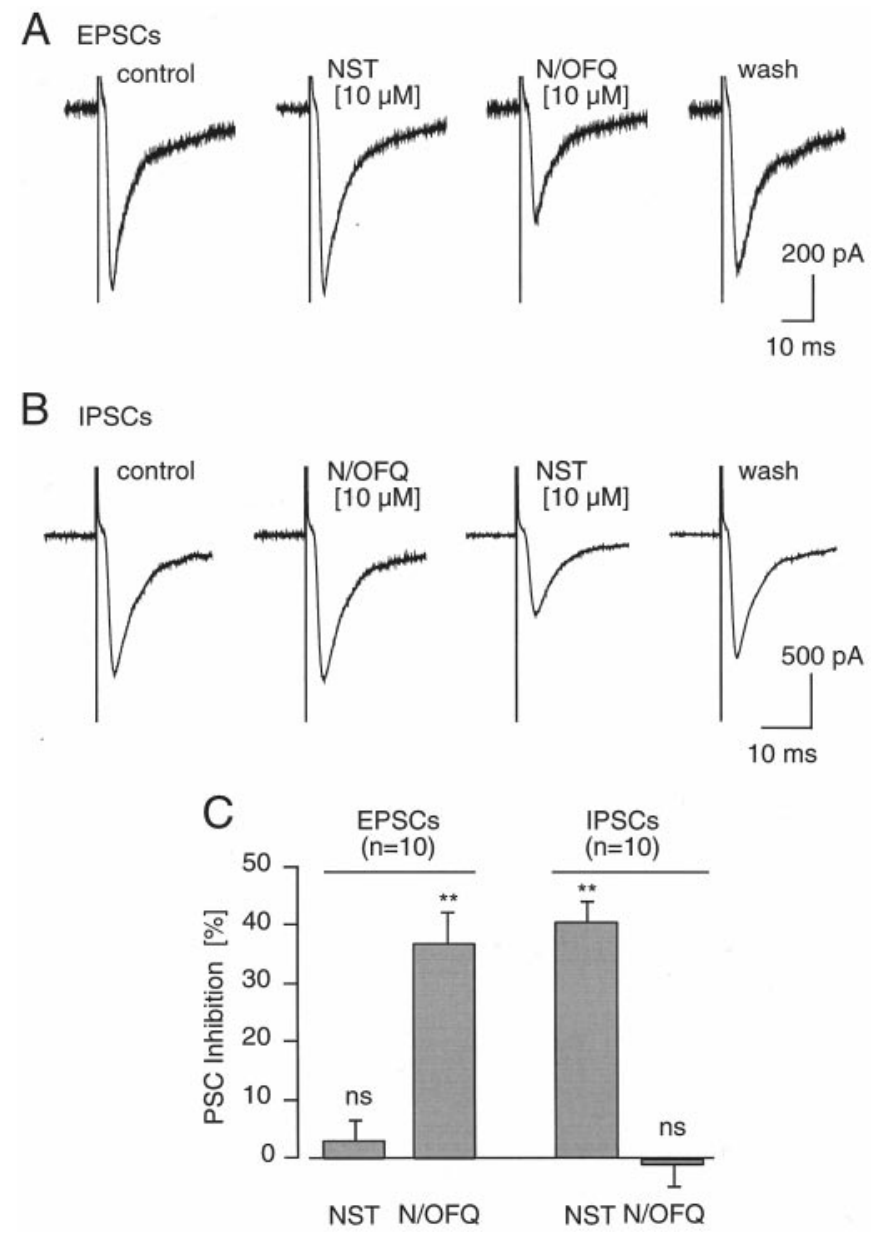

Fig. 1. Selective modulation of EPSCs and IPSCs by N/OFQ and NST in wild-type mice. EPSCs (A) and IPSCs (B) were recorded at $-80 \mathrm{mV}$ in isolation after blockade of ionotropic glutamate receptors with CNQX and APV and of glycine and $\mathrm{GABA}_{\mathrm{A}}$ receptors with strychnine and bicuculline, respectively (for details, see Results section). Top, current traces averaged from 10 consecutive stimulations recorded under control conditions (control), in the presence of NST $(10 \mu \mathrm{M})$ or N/OFQ $(10 \mu \mathrm{M})$, and after removal of the peptides (wash). C, average EPSC and IPSC inhibition (mean \pm S.E.M.) by NST and N/OFQ (both $10 \mu \mathrm{M}$ ). ** $p \leq 0.01$; ns, statistically not significant (one sample sign test).
In a separate set of experiments, we investigated the concentration dependence of this effect (Fig. 2C). In wild-type mice, bath application of N/OFQ $(0.1-10 \mu \mathrm{M})$ lead to a concentration-dependent reduction of the EPSC amplitudes. At the highest concentration tested $(10 \mu \mathrm{M})$, the EPSC amplitudes were reduced by $45.1 \pm 5.4 \%(n=6)$. Marked inhibition $(20.3 \pm 3.7 \%, n=4)$ was still observed at $1 \mu \mathrm{M}$. In contrast, inhibition was nearly absent in N/OFQ- $\mathrm{R}^{-/-}$littermates. Even at a concentration of $10 \mu \mathrm{M}$, no significant reduction was seen ( $\Delta$ EPSC amplitude: $5.5 \pm 2.52 \% ; n=6$ ).

Further experiments were performed to demonstrate that the observed lack of modulation of excitatory transmission by $\mathrm{N} / \mathrm{OFQ}$ in the N/OFQ-R $\mathrm{R}^{-/-}$mice was indeed caused by the lack of N/OFQ receptors and not by a disturbance of downstream modulatory elements. In these experiments, we used met-enk (10 $\mu \mathrm{M})$, which suppresses spinal glutamatergic synaptic transmission via receptors different from the N/OFQ receptor (Liebel et al., 1997), probably via $\delta$ and $\mu$ opioid receptors (Goldstein and Naidu, 1989). As shown in Fig. 3, met-enk (10 $\mu \mathrm{M})$ inhibited EPSCs in all three genotypes by a similar degree.
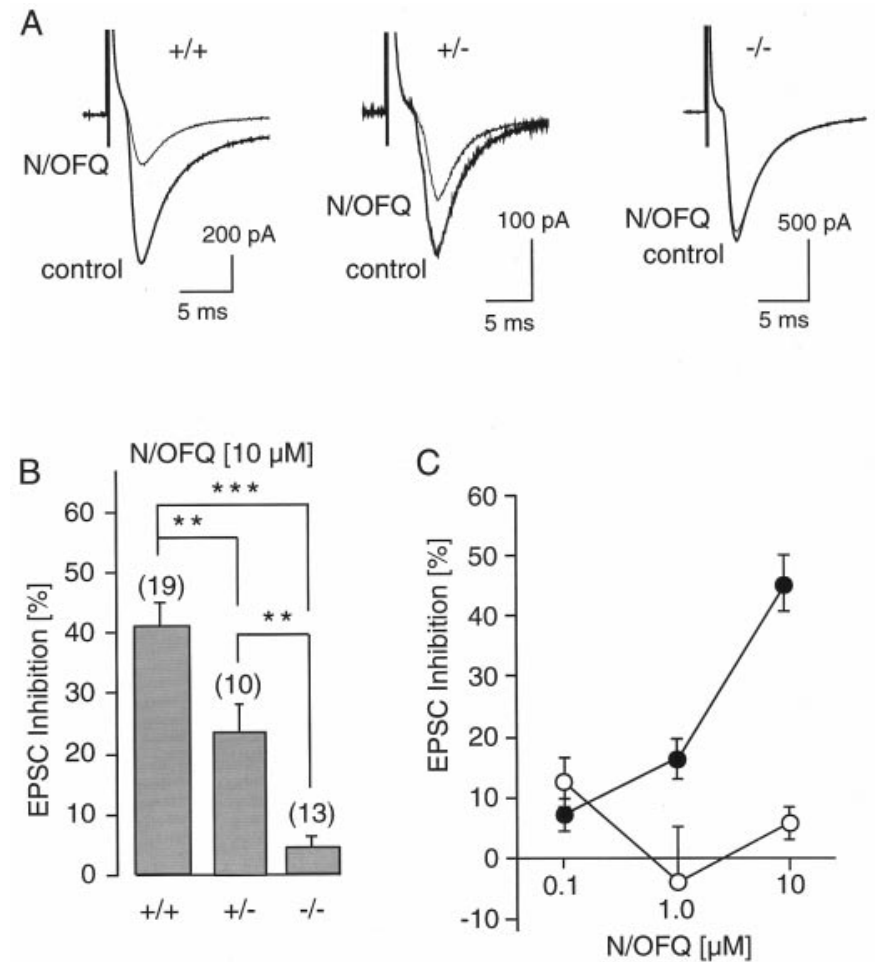

Fig. 2. Lack of N/OFQ-mediated inhibition of excitatory glutamatergic synaptic transmission in N/OFQ- $\mathrm{R}^{-1-}$ mice. A, EPSC traces averaged from 10 consecutive stimulations recorded under control conditions (control) and in the presence of N/OFQ $(10 \mu \mathrm{M})$, in wild-type mice $(+/+)$, heterozygous mice $(+/-)$, and N/OFQ receptor-deficient mice $(-/-)$. B, gene dose effect: percentage inhibition of EPSC amplitudes (mean \pm S.E.M.) by N/OFQ $(10 \mu \mathrm{M})$ in wild-type mice $(+/+)$, heterozygous mice $(+/-)$ and N/OFQ- $\mathrm{R}^{-/-}$mice $(-/-)$. Numbers in parentheses, number of cells. Statistical differences were analyzed by ANOVA followed by Fisher's post hoc test. $* p \leq 0.05 ; * * \leq 0.01 ; * * * p \leq 0.001$. C, percentage inhibition of EPSC amplitudes (mean \pm S.E.M.) by different concentra-

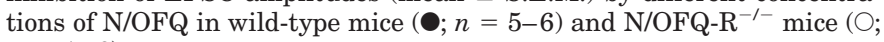
$n=4-6)$. 
Inhibition of Spinal IPSCs by NST is retained in N/OFQ-R ${ }^{-/-}$Mice. In contrast to EPSC inhibition by $\mathrm{N} / \mathrm{OFQ}$, inhibition by NST of IPSCs was completely retained in N/OFQ- $\mathrm{R}^{-1-}$ mice (Fig. 4A). Statistically significant inhibition by NST $(10 \mu \mathrm{M})$ was achieved in all three genotypes ( $\triangle$ IPSC amplitude $35.5 \pm 4.0 \% ; 44.8 \pm 3.5 \%$, and $49.4 \pm$ $6.1 \% ; n=7-19 ; p \leq 0.05-0.001)$. No statistically significant differences were found in the degree of inhibition by $10 \mu \mathrm{M}$ NST (ANOVA, at $\alpha=0.05$; Fig. 4B) between the different genotypes. When NST was applied in different concentrations ranging from 0.1 to $10 \mu \mathrm{M}$, no significant difference in the concentration dependence was detected (Fig. 4C).

The Antinociceptive Effect of N/OFQ Is Absent in N/OFQ-R ${ }^{-/-}$Mice. The inhibitory effects of N/OFQ on spinal glutamatergic synaptic transmission are similar to those of classical opioids like morphine and may well underlie the spinal antinociceptive effects of N/OFQ seen after intrathecal injection of nanomolar doses. Because the cellular effects of $\mathrm{N} / \mathrm{OFQ}$ on spinal neurotransmission were absent in $\mathrm{N} / \mathrm{OFQ}-\mathrm{R}^{-1-}$ mice, we tested whether these mice also lacked the antinociceptive effects of spinally applied N/OFQ. When $\mathrm{N} / \mathrm{OFQ}(3 \mathrm{nmol} /$ mouse in $5 \mu \mathrm{l}$ of ACSF) was injected intrathecal to the lumbar spinal cord of wild-type mice, a statistically significant reduction of the number of flinches as compared with vehicle ( $5 \mu \mathrm{l}$ of ACSF)-injected wild-type mice was observed during both phases of the formalin test (Fig. 5, $\mathrm{A}$ and $\mathrm{B}$ ). By contrast, $\mathrm{N} / \mathrm{OFQ}-\mathrm{R}^{-1-}$ mice exhibited no change in nociceptive behavior after injection of $\mathrm{N} / \mathrm{OFQ}$ compared with vehicle-injected mice (Fig. 5, C and D).

Both vehicle-injected wild-type and N/OFQ- $\mathrm{R}^{-/-}$mice showed a nearly identical number of flinches/min during phase I (1-10 min after formalin injection) of the formalin test $(8.29 \pm 1.33$ versus $9.20 \pm 1.75 ; n=10)$. However, during phase II (20-60 min), N/OFQ- $\mathrm{R}^{-1-}$ exhibited markedly increased nociceptive behavior $(5.80 \pm 1.49$ versus $3.45 \pm 0.46$ flinches $/ \mathrm{min} ; n=10$ ). No signs of motor dysfunction were observed after intrathecal injection of N/OFQ.

\section{Discussion}

In previous reports, we have shown that NST selectively reduces the amplitudes of GABAergic and glycinergic IPSCs in the rat spinal cord, whereas $\mathrm{N} / \mathrm{OFQ}$ interferes only with excitatory glutamatergic synaptic transmission (Liebel et al., 1997; Zeilhofer et al., 2000). In the present study, we provide direct evidence that the inhibitory effect of N/OFQ on spinal glutamatergic synaptic transmission as well as the antinociceptive effects of spinally administered N/OFQ are mediated by N/OFQ receptors, whereas the functional N/OFQ antagonist NST acts via a different receptor.

N/OFQ-Mediated Inhibition of Spinal Glutamatergic Transmission Occurs via N/OFQ Receptors. The inhibition of EPSCs by N/OFQ in the rat spinal cord dorsal horn occurred at relatively high concentrations, with an $\mathrm{EC}_{50}$ value in the range of 400 to $500 \mathrm{nM}$ (Liebel et al., 1997). $\mathrm{N} / \mathrm{OFQ}$ has been reported to be significantly more potent in other preparations. In the rat CNS, activation of G proteincoupled inwardly rectifying potassium currents (Meis and Pape, 1998) and inhibition of $\mathrm{Ca}^{2+}$ currents (Connor et al., 1999) by N/OFQ occur with $\mathrm{EC}_{50}$ values in the low nanomolar range. A possible explanation for these apparent differences in potency might be that $\mathrm{N} / \mathrm{OFQ}$ acts via more than one receptor type. There is indeed evidence for two different binding sites with different affinities for N/OFQ (Mathis et al., 1997). Furthermore, in a recent report, it has been proposed that an eleven amino acid N/OFQ fragment (N/OFQ[111]) might specifically bind to a low affinity $\mathrm{N} / \mathrm{OFQ}$ binding site, which is different from the N/OFQ receptor found in Chines hamster ovary cells transfected with the N/OFQ receptor (opioid receptor-like 1) gene (Letchworth et al., 2000).

On the other hand, the results obtained here demonstrate unambiguously that inhibition of excitatory neurotransmission by N/OFQ as well as its antinociceptive action in the formalin test are mediated via receptors encoded by the $\mathrm{N} / \mathrm{OFQ}$ receptor gene. Our finding that inhibition of excitatory neurotransmission by the classical opioid peptide metenk was retained in N/OFQ- $\mathrm{R}^{-1-}$ mice, excludes the possibility that the disruption of the N/OFQ receptor gene not only prevented modulation by N/OFQ, but also affected modulation of excitatory synaptic transmission in general. This is further rendered unlikely by our in vivo finding that the baseline sensitivity to nociceptive stimuli, as assessed in the first phase of the formalin test, was nearly identical in $\mathrm{N} / \mathrm{OFQ}-\mathrm{R}^{-/-}$and wild-type mice.

Our results are therefore in line with previous results by
A

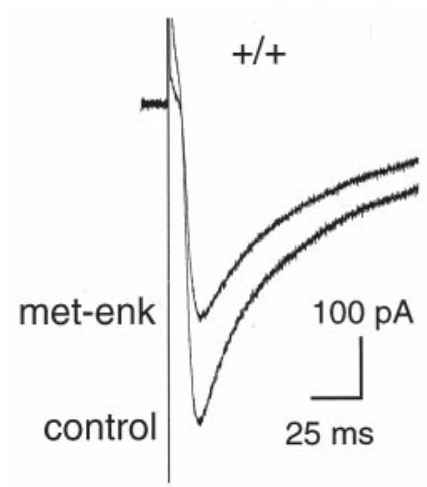

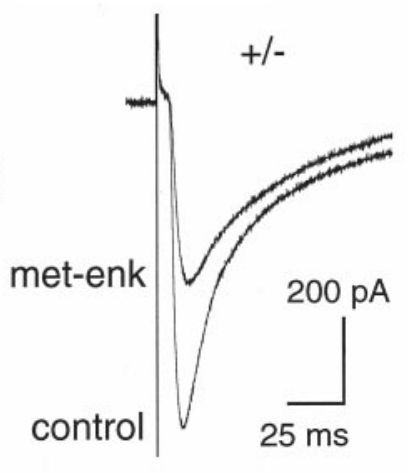

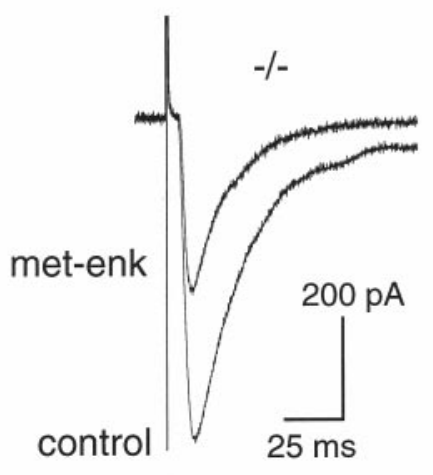

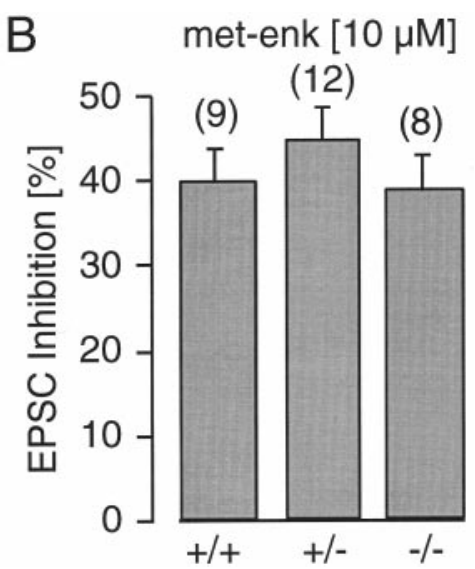

Fig. 3. Modulation of excitatory glutamatergic synaptic transmission by met-enk is retained in N/OFQ- $\mathrm{R}^{-/-}$mice. A, EPSC traces averaged from 10 consecutive stimulations recorded under control conditions (control) and in the presence of met-enk $(10 \mu \mathrm{M})$, in wild-type mice (+/+), heterozygous mice $(+/-)$, and N/OFQ- $\mathrm{R}^{-1-}$ mice $(-/-)$. B, percentage inhibition of EPSC amplitudes (mean \pm S.E.M.) by met-enk $(10 \mu \mathrm{M})$ in wild-type mice $(+/+)$, heterozygous mice $(+/-)$, and N/OFQ- $\mathrm{R}^{-1-}$ mice $(-/-)$. 
Inoue et al. (1999), who have shown that $\mathrm{N} / \mathrm{OFQ}-\mathrm{R}^{-/-}$mice lack the inhibitory effect of intrathecal-injected N/OFQ on substance P-induced nociceptive responses. They do not, however, exclude the possibility that the effects of $\mathrm{N} / \mathrm{OFQ}$ occur via receptor subtypes different from the "classical" $\mathrm{N} / \mathrm{OFQ}$ receptor, which might originate from post-transcriptional modifications. The existence of different splice variants of the mouse N/OFQ receptor has indeed been demonstrated (Wang et al., 1994; Pan et al., 1998).

There are, however, other possible explanations for differing potencies. The potency of agonists at G protein-coupled receptors is not solely determined by their receptor affinities, but also depends on the number of functional receptors expressed in relation to the number of available downstream transducer molecules (e.g., G proteins). The pronounced gene-dose effect seen in our experiments may indicate that the number of $\mathrm{N} / \mathrm{OFQ}$ receptors is the limiting factor for $\mathrm{N} / \mathrm{OFQ}$-mediated EPSC inhibition. The differences in potency of N/OFQ in different CNS preparations, therefore, may very well reflect differences in the amount of $\mathrm{N} / \mathrm{OFQ}$ receptor expression. In vivo, differing levels of receptor expression may also explain in part why N/OFQ-mediated effects strongly depend on the dose and site of administration of $\mathrm{N} / \mathrm{OFQ}$.

N/OFQ in the Formalin Test. In our experiments, we have tested the effects of $\mathrm{N} / \mathrm{OFQ}$ in a tonic pain model that allows monitoring of spontaneous nociceptive behavior for $1 \mathrm{~h}$. In this test, spinally applied N/OFQ (3 nmol/mouse) exhibited antinociceptive effects that were completely absent in $\mathrm{N} / \mathrm{OFQ}-\mathrm{R}^{-/-}$mice, indicating that the antinociceptive action of $\mathrm{N} / \mathrm{OFQ}$ is mediated by the $\mathrm{N} / \mathrm{OFQ}$ receptor.
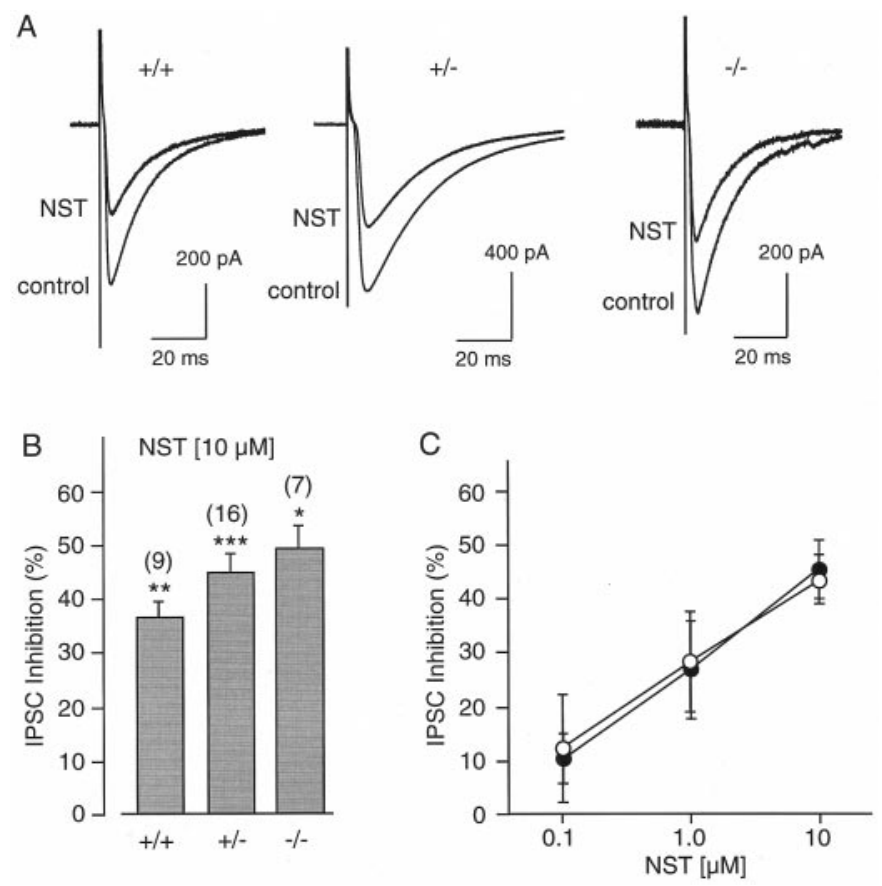

Fig. 4. Modulation of inhibitory synaptic transmission by NST is retained in N/OFQ- $\mathrm{R}^{-1-}$ mice. A, IPSC traces averaged from 10 consecutive stimulations recorded under control conditions (control) and in the presence of NST $(10 \mu \mathrm{M})$, in wild-type mice $(+/+)$, heterozygous mice $(+/-)$ and $\mathrm{N} / \mathrm{OFQ}-\mathrm{R}^{-/-}$mice $(-/-) . \mathrm{B}$, gene dose effect: percentage inhibition of IPSC amplitudes (mean \pm S.E.M.) by NST $(10 \mu \mathrm{M})$ in wild-type mice $(+/+)$, heterozygous mice $(+/-)$, and N/OFQ- $\mathrm{R}^{-/-}$mice $(-/-) .{ }^{*} p \leq 0.05$; $* * p \leq 0.01 ; * * * p \leq 0.001$ (one sample sign test). C, percentage inhibition of IPSC amplitudes (mean \pm S.E.M.) by different concentrations of NST in wild-type mice $(\bullet ; n=4)$ and N/OFQ- $\mathrm{R}^{-1-}$ mice $(\bigcirc ; n=6)$.
In vivo studies have suggested that N/OFQ acts synergistically with opioid peptides at the spinal cord level but as a functional antiopioid at supraspinal levels (Tian et al., 1997). Our electrophysiological results provide evidence that N/OFQ exerts its spinal antinociceptive action by specifically reducing glutamatergic transmission in the spinal cord dorsal horn, thereby via a mechanism that is indeed similar to that of classical opioid peptides. In the brain stem, however, N/OFQ inhibits both excitatory and inhibitory neurons (Pan et al., 2000), whereas agonists at $\mu$-opioid receptors mainly interfere with GABAergic interneurons (Pan et al., 1997; Vaughan et al., 1997). Synergistic versus antagonistic effects of N/OFQ and classical opioidergic agonists may thus depend on their respective neuronal target populations.

The use of N/OFQ-R-deficient mice also opens the possibility to test for effects of endogenous N/OFQ. Most investigators thus far have found no evidence for an antinociceptive effect of endogenous N/OFQ. However, N/OFQ- $\mathrm{R}^{-1-}$ mice have mainly been evaluated in rather acute pain models, such as the tail-flick test; in other cases, nociceptive behavior has been followed for only relatively short periods of time (e.g., $10 \mathrm{~min}$ in the mouse abdominal constriction; Nishi et al., 1997). Therefore, it seems possible that nociceptive stimulation has been too short to elicit endogenous release of
A

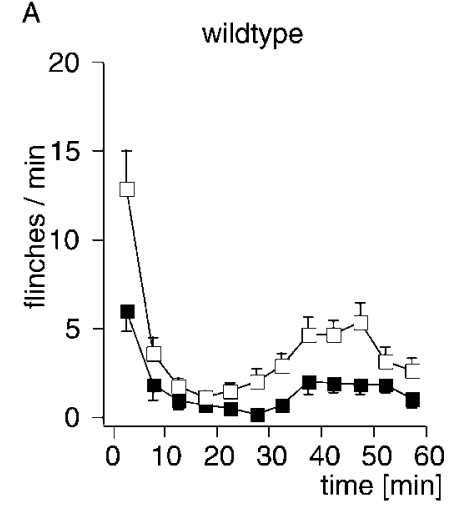

C

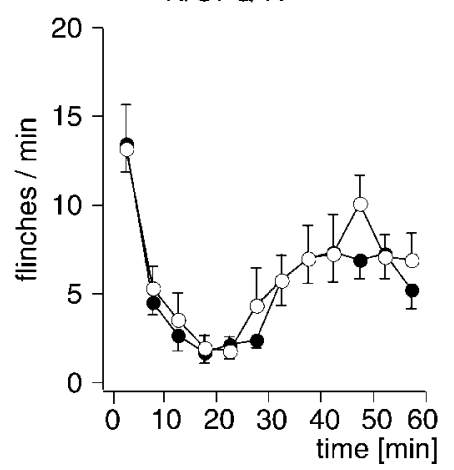

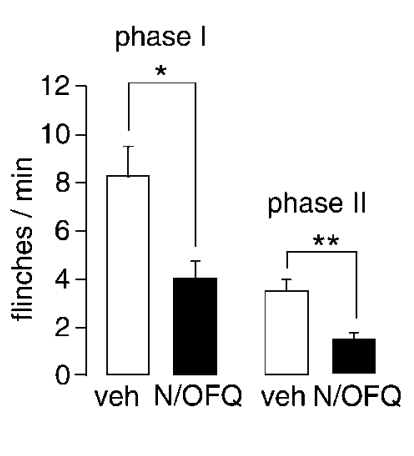

Fig. 5.: Effects of N/OFQ in the formalin test in N/OFQ- $\mathrm{R}^{-1-}$ mice. A and $\mathrm{C}$, number of flinches/min (mean \pm S.E.M.) of the injected paw averaged for intervals of $5 \mathrm{~min}$ in wild-type mice (squares) and N/OFQ-R ${ }^{-1-}$ mice (circles) after intrathecal injection of either vehicle ( $5 \mu \mathrm{l}$; open symbols) or N/OFQ ( $3 \mathrm{nmol} / \mathrm{mouse}$ in a total volume of $5 \mu \mathrm{l}$; filled symbols). B and D, average number of flinches/min (mean \pm S.E.M.) during phase I (1-10 min after formalin injection) and phase II (21-60 min). Open bars, vehicle (veh)-treated mice; filled bars, N/OFQ (3 nmol/mouse, intrathecal injection)-treated mice. ${ }^{*} p \leq 0.05 ; * * p \leq 0.01$; ns, statistically not significant (ANOVA followed by Fisher's post hoc test). 
$\mathrm{N} / \mathrm{OFQ}$. Indeed, in the formalin test described in our report, nociceptive behavior of vehicle-injected wild-type and N/OFQ-R ${ }^{-/-}$mice was nearly identical during phase I (1-10 $\mathrm{min})$. However, during phase II (20-60 $\mathrm{min}), \mathrm{N} / \mathrm{OFQ}-\mathrm{R}^{-/-}$ mice showed an increased flinching behavior, which may suggest a role of endogenous N/OFQ in pain modulation. These findings support those earlier reported by Tian et al. (1998), who used antibodies against N/OFQ to test for effects of endogenous N/OFQ.

The role of endogenous N/OFQ in nociceptive behavior has also been investigated in mice lacking the gene encoding for the N/OFQ precursor protein (Köster et al., 1999). These mice showed impaired adaptation to stressful environment, but no changes in the tail-flick test as long as they were kept in isolation. Changes in nociceptive thresholds observed in group-housed mice were attributed to the higher stress susceptibility of $\mathrm{ppN} / \mathrm{OFQ}^{-/-}$mice. The lack of a nociceptive phenotype in these mice might again be explained by the use of an acute versus a tonic pain model. Another explanation might be that these mice lack not only N/OFQ but also other biologically active peptides potentially released from the same precursor peptide, such as NST or orphanin FQ 2 (Rossi et al., 1998). The simultaneous lack of more than one peptide might then compensate the effect of the missing N/OFQ in these mice.

Effects of N/OFQ and NST Occur via Different Receptors. Although the inhibitory effect of N/OFQ on EPSCs was completely absent in N/OFQ- $\mathrm{R}^{-/-}$mice and strongly reduced in N/OFQ- $\mathrm{R}^{+/-}$mice, inhibition of IPSCs by NST remained unchanged. These results clearly show that N/OFQ and NST act via separate receptors and demonstrate that the synaptic effects of NST do not depend on the presence of functional N/OFQ receptors. Our results therefore confirm those of others who have demonstrated that NST does not compete with N/OFQ for N/OFQ receptor binding (Okuda-Ashitaka et al., 1998) and that NST neither mimics nor blocks N/OFQ receptormediated $\mathrm{Ca}^{2+}$ current inhibition (Connor et al., 1999). Together with our previous finding that the synaptic effects of NST depend on the activation of pertussis toxin-sensitive G proteins (Zeilhofer et al., 2000), these results indicate that NST is a biologically active peptide per se, which activates a membrane receptor that has yet to be identified.

Conclusion and Implications. The observation that $\mathrm{N} / \mathrm{OFQ}-\mathrm{R}^{-/-}$mice lack both the inhibitory effect of N/OFQ on glutamatergic neurotransmission and the antinociceptive activity of spinally applied N/OFQ strengthens the possibility that the synaptic action of N/OFQ underlies the antinociceptive action observed in vivo. In this respect, the action of $\mathrm{N} / \mathrm{OFQ}$ resembles that of classical opioid peptides at the spinal cord level. In higher brain areas, however, where most of the unwanted opioid effects arise, activation of N/OFQ receptors by N/OFQ or by nonpeptide N/OFQ receptor agonists seems to exert anti-opioidergic (Mogil et al., 1996) and anxiolytic (Jenck et al., 2000) effects. The combination of opioid-like analgesia at the spinal cord level and anti-opioidergic (Mogil et al., 1996) and anxiolytic activity (Köster et al., 1999; Jenck et al., 2000) in higher brain areas makes the N/OFQ system a promising target for the development of new analgesics possibly devoid of the unwanted side effects of classical opioids.

\section{Acknowledgments}

We thank Dr. Rachel Jurd for critical reading of the manuscript and Susanne Gabriel and Beate Layh for excellent technical assistance.

\section{References}

Ahmadi S, Liebel JT and Zeilhofer HU (2001) The role of the ORL1 receptor in the modulation of spinal neurotransmission by nociceptin orphanin FQ and nocistatin. Eur J Pharmacol, in press.

Bunzow JR, Saez C, Mortrud M, Bouvier C, Williams JT, Low M and Grandy DK (1994) Molecular cloning and tissue distribution of a putative member of the rat opioid receptor gene family that is not a mu, delta or kappa opioid receptor type. FEBS Lett 347:284-288.

Calo' G, Guerrini R, Rizzi A, Salvadori S and Regoli D (2000) Pharmacology of nociceptin and its receptor: A novel therapeutic target. Br J Pharmacol 129:12611283.

Connor M, Vaughan CW, Jennings EA, Allen RG and Christie MJ (1999) Nociceptin, $\mathrm{Phe}^{1} \psi$-nociceptin ${ }_{1-13}$, nocistatin and prepronociceptin ${ }_{154-181}$ effects on calcium channel currents and a potassium current in rat locus coeruleus in vitro. $\mathrm{Br} J$ Pharmacol 128:1779-1787.

Dodt H-U and Zieglgänsberger W (1994) Infrared videomicroscopy: A new look at neuronal structure and function. Trends Neurosci 17:453-458.

Doubell TP, Mannion RJ and Woolfe CJ (1999) The dorsal horn: State-dependent sensory processing, plasticity and the generation of pain, in Textbook of Pain (Wall PD, Melzack R eds) pp 165-181, Edinborough, Churchill Livingston.

Dubuisson D and Dennis SG (1977) The formalin test: A quantitative study of the analgesic effects of morphine, meperidine, and brain stem stimulation in rats and cats. Pain 4:161-174.

Erb K, Liebel JT, Tegeder I, Zeilhofer HU, Brune K and Geisslinger G (1997) Spinally delivered nociceptin/orphanin FQ reduces flinching behaviour in the rat formalin test. Neuroreport 8:1967-1970.

Fukuda K, Kato S, Mori K, Nishi M, Takeshima H, Iwabe N, Miyata T, Houtani T and Sugimoto T (1994) cDNA cloning and regional distribution of a novel member of the opioid receptor family. FEBS Lett 343:42-46.

Goldstein A and Naidu A (1989) Multiple opioid receptors: Ligand selectivity profiles and binding site signatures. Mol Pharmacol 36:265-272.

Guerrini R, Calo G, Rizzi A, Bigoni R, Bianchi C, Salvadori S and Regoli D (1998) A new selective antagonist of the nociceptin receptor. $B r J$ Pharmacol 123:163-165.

Houtani T, Nishi M, Takeshima H, Nukada T and Sugimoto T (1996) Structure and regional distribution of nociceptin/orphanin FQ precursor. Biochem Biophys Res Commun 219:714-719.

Houtani T, Nishi M, Takeshima H, Sato K, Sakuma S, Kakimoto S, Ueyama T, Noda $\mathrm{T}$ and Sugimoto T (2000) Distribution of nociceptin/orphanin FQ precursor protein and receptor in brain and spinal cord: A study using in situ hybridization and X-gal histochemistry in receptor-deficient mice. J Comp Neurol 424:489-508.

Inoue M, Shimohira I, Yoshida A, Zimmer A, Takeshima H, Sakurada T and Ueda H (1999) Dose-related opposite modulation by nociceptin/orphanin FQ of substance $\mathrm{P}$ nociception in the nociceptors and spinal cord. J Pharmacol Exp Ther 291:308313

Jenck F, Wichmann J, Dautzenberg FM, Moreau JL, Ouagazzal AM, Martin JR, Lundstrom K, Cesura AM, Poli SM, Roever S, Kolczewski S, Adam G and Kilpatrick G (2000) A synthetic agonist at the orphanin FQ/nociceptin receptor ORL1: Anxiolytic profile in the rat. Proc Natl Acad Sci USA 97:4938-4943.

Köster A, Montkowski A, Schulz S, Stube EM, Knaudt K, Jenck F, Moreau JL, Nothacker HP, Civelli O and Reinscheid RK (1999) Targeted disruption of the orphanin $\mathrm{FQ} /$ nociceptin gene increases stress susceptibility and impairs stress adaptation in mice. Proc Natl Acad Sci USA 96:10444-10449.

Letchworth SR, Mathis JP, Rossi GC, Bodnar RJ and Pasternak GW (2000) Autoradiographic localization of $\left.{ }^{125} \mathrm{I}^{1} \mathrm{Tyr}^{14}\right]$ orphanin $\mathrm{FQ} /$ nociceptin and ${ }^{125} \mathrm{I} \mathrm{Tyr}^{10}{ }^{10}$ orphanin $\mathrm{FQ} /$ nociceptin(1-11) binding sites in rat brain. J Comp Neurol 423:319-329.

Liebel JT, Swandulla D and Zeilhofer HU (1997) Modulation of excitatory synaptic transmission by nociceptin in superficial dorsal horn neurones of the neonatal rat spinal cord. Br J Pharmacol 121:425-432.

Mathis JP, Ryan-Moro J, Chang A, Hom JS, Scheinberg DA and Pasternak GW (1997) Biochemical evidence for orphanin FQ/nociceptin receptor heterogeneity in mouse brain. Biochem Biophys Res Commun 230:462-465.

Meis S and Pape HC (1998) Postsynaptic mechanisms underlying responsiveness of amygdaloid neurons to nociceptin/orphanin FQ. J Neurosci 18:8133-8144.

Meunier JC, Mollereau C, Toll L, Suaudeau C, Moisand C, Alvinerie P, Butour JL, Guillemot JC, Ferrara P, Monsarrat B, Mazarguil H, Vassart G, Parmentier M and Costentin J (1995) Isolation and structure of the endogenous agonist of opioid receptor-like ORL1 receptor. Nature (Lond) 377:532-535.

Minami T, Okuda-Ashitaka E, Nishiuchi Y, Kimura T, Tachibana S, Mori and Ito S (1998) Anti-nociceptive responses produced by human putative counterpart of nocistatin. Br J Pharmacol 124:1016-1018.

Mogil JS, Grisel JE, Reinscheid RK, Civelli O, Belknap JK and Grandy DK (1996) Orphanin FQ is a functional anti-opioid peptide. Neuroscience 27:333-337.

Mollereau C, Simons MJ, Soularue P, Liners F, Vassart G, Meunier JC and Parmentier M (1994) ORL1, a novel member of the opioid receptor family. Cloning, functional expression and localization. FEBS Lett 341:33-38.

Nakano H, Minami T, Abe K, Arai T, Tokumura M, Ibii N, Okuda-Ashitaka E, Mori $\mathrm{H}$ and Ito $\mathrm{S}$ (2000) Effect of intrathecal nocistatin on the formalin-induced pain in mice versus that of nociceptin/orphanin FQ. J Pharmacol Exp Ther 292:331-336.

Narita M, Mizoguchi H, Oji DE, Dun NJ, Hwang BH, Nagase H and Tseng LF (1999) Identification of the G-protein-coupled ORL1 receptor in the mouse spinal cord by $\left[{ }^{35} \mathrm{~S}\right]-$ GTP $\gamma \mathrm{S}$ binding and immunohistochemistry. Br J Pharmacol 128:1300-1306 Nicol B, Lambert DG, Rowbotham DJ, Okuda-Ashitaka E, Ito S, Smart D and 
McKnight AT (1998) Nocistatin reverses nociceptin inhibition of glutamate release from rat brain slices. Eur $J$ Pharmacol 356:R1-3.

Nishi M, Houtani T, Noda Y, Mamiya T, Sato K, Doi T, Kuno J, Takeshima H, Nukada T, Nabeshima T, Yamashita T, Noda T and Sugimoto T (1997) Unrestrained nociceptive response and disregulation of hearing ability in mice lacking the nociceptin/orphaninFQ receptor. EMBO $J$ 16:1858-1864

Nishi M, Takeshima H, Mori M, Nakagawara K and Takeuchi T (1994) Structure and chromosomal mapping of genes for the mouse kappa-opioid receptor and an opioid receptor homologue (MOR-C). Biochem Biophys Res Commun 205:13531357.

Nothacker HP, Reinscheid RK, Mansour A, Henningsen RA, Ardati A, Monsma FJ Jr, Watson SJ and Civelli O (1996) Primary structure and tissue distribution of the orphanin FQ precursor. Proc Natl Acad Sci USA 93:8677-8682.

Okuda-Ashitaka E, Minami T, Tachibana S, Yoshihara Y, Nishiuchi Y, Kimura T and Ito $\mathrm{S}$ (1998) Nocistatin, a peptide that blocks nociceptin action in pain transmission. Nature (Lond) 392:286-289.

Pan YX, Xu J and Pasternak GW (1996) Cloning and expression of a cDNA encoding a mouse brain orphanin $\mathrm{FQ} /$ nociceptin precursor. Biochem $J$ 315:11-13.

Pan YX, Xu J, Wan BL, Zuckerman A and Pasternak GW (1998) Identification and differential regional expression of KOR-3/ORL-1 gene splice variants in mouse brain. FEBS Lett 435:65-68.

Pan Z, Hirakawa N and Fields HL (2000) A cellular mechanism for the bidirectional pain-modulating actions of orphanin FQ/nociceptin. Neuron 26:515-522.

Pan ZZ, Tershner SA and Fields HL (1997) Cellular mechanism for anti-analgesic action of agonists of the kappa-opioid receptor. Nature (Lond) 389:382-385

Reinscheid RK, Nothacker HP, Bourson A, Ardati A, Henningsen RA, Bunzow JR, Grandy DK, Langen H, Monsma FJ Jr and Civelli O (1995) Orphanin FQ a neuropeptide that activates an opioidlike G protein-coupled receptor. Science (Wash DC) 270:792-794.

Rossi GC, Mathis JP and Pasternak GW (1998) Analgesic activity of orphanin FQ2, murine prepro-orphanin FQ141-157 in mice. Neuroreport 9:1165-1168.

Saito Y, Maruyama K, Saido TC and Kawashima S (1995) N23K, a gene transiently up-regulated during neural differentiation, encodes a precursor protein for a newly identified neuropeptide nociceptin. Biochem Biophys Res Commun 217:539-545.
Tian JH, Xu W, Fang Y, Mogil JS, Grisel JE, Grandy DK and Han JS (1997) Bidirectional modulatory effect of orphanin FQ on morphine-induced analgesia: Antagonism in brain and potentiation in spinal cord of the rat. $\mathrm{Br} J$ Pharmaco 120:676-680

Tian JH, Zhang W, Fang Y, Xu W, Grandy DK and Han JS (1998) Endogenous orphanin FQ: Evidence for a role in the modulation of electroacupuncture analgesia and the development of tolerance to analgesia produced by morphine and electroacupuncture. $\mathrm{Br}$ J Pharmacol 124:21-26.

Vaughan CW, Ingram SL, Connor MA and Christie MJ (1997) How opioids inhibit GABA-mediated neurotransmission. Nature (Lond) 390:611-614

Wang JB, Johnson PS, Imai Y, Persico AM, Ozenberger BA, Eppler CM and Uhl GR (1994) cDNA cloning of an orphan opiate receptor gene family member and its splice variant. FEBS Lett 348:75-79.

Xu IS, Hashemi M, Calo G, Regoli D, Wiesenfeld-Hallin Z and Xu XJ (1999) Effects of intrathecal nocistatin on the flexor reflex and its interaction with orphanin FQ nociceptin. Neuroreport 10:3681-3684.

Xu XJ, Hao JX and Wiesenfeld-Hallin Z (1996) Nociceptin or antinociceptin: Potent spinal antinociceptive effect of orphanin FQ/nociceptin in the rat. Neuroreport 7:2092-2094.

Yaksh TL and Malmberg AB (1994) Central pharmacology of nociceptive transmission, in Textbook of Pain (Wall PD, Melzack R eds) pp 165-200, Edinborough, Churchill Livingston.

Zeilhofer HU, Muth-Selbach U, Guhring H, Erb K and Ahmadi S (2000) Selective suppression of inhibitory synaptic transmission by nocistatin in the rat spinal cord dorsal horn. $J$ Neurosci 20:4922-4929.

Zhao CS, Li BS, Zhao GY, Liu HX, Luo F, Wang Y, Tian JH, Chang JK and Han JS (1999) Nocistatin reverses the effect of orphanin FQ/nociceptin in antagonizing morphine analgesia. Neuroreport 10:297-299.

Send reprint requests to: Dr. H.U. Zeilhofer, Institut für Pharmakologie und Toxikologie, Universität Zürich, Winterthurerstrasse 190, CH-8057 Zürich, Switzerland. E-mail: zeilhofe@pharma.unizh.ch 